\title{
Biofilm production and biocidal efficacy in multidrug-resistant Pseudomonas aeruginosa and Acinetobacter baumannii isolates
}

\author{
Burcu SEBiT, Burak AKSU, Ayșegül KARAHASAN YAĞCI
}

Marmara University Faculty of Medicine, Department of Microbiology and Medical Microbiology, İstanbul-Turkey

\begin{abstract}
SUMMARY
Objective: Nosocomial infections caused by resistant Gram-negative bacilli have become a major problem for hospitals in recent years. Antiseptics and disinfectants play an important role in the prevention of nosocomial infections and in the management of infections. Some Gram-negative bacilli also show resistance to antiseptics and disinfectants. Therefore, the selection of proper antiseptics and disinfectants is crucial to prevent nosocomial infections produced by these resistant organisms. In this study, we investigated the biofilm production, antimicrobial susceptibility, and biocidal activity of commonly used antiseptics and disinfectants in our hospital setting against Pseudomonas aeruginosa and Acinetobacter baumannii isolates.
\end{abstract}

Methods: Between January and December-2014, a total of 50 Pseudomonas aeruginosa and 50 Acinetobacter baumannii strains, which were multidrug-resistant (MDR) strains, were included in this study. Biofilm production was identified spectrophotometrically by the microplate assay. Activity of sodium hypochlorite, chlorhexidine, orthophthalaldehyde (OPA), peracetic acid (PA), and peracetic acid/hydrogen peroxide was studied with suspension tests.

Results: Commonly used disinfectant-antiseptics were found to be effective against multi-drug resistant A. baumannii and P. aeruginosa strains as follows, chlorhexidine $98 \%$, sodium hypochlorite $90 \%$, OPA $96 \%$, PA and peracetic acid/hydrogen peroxide $94 \%$. The rates of efficacy against the antibioticsusceptible A. baumannii and P. aeruginosa were found to be $100 \%$ for chlorhexidine, OPA and PA, $98 \%$ for sodium hypochlorite, and $94 \%$ for peracetic acid/ hydrogen peroxide. Considering the relationship between the biofilm production and biocidal activity, $22 \%$ of biofilm-producing strains of A. baumannii were found to be resistant to any all disinfectants-antiseptics tested, while this rate was $2 \%$ in the $P$. aeruginosa strains. Disinfectant resistance rates were $2 \%$ and $6 \%$ for biofilm-negative $A$. baumannii and, P. aeruginosa strains, respectively. Biofilm production and disinfectant resistance were found to be significantly associated with $A$. baumannii, compared to P. aeruginosa $(\mathrm{p}<0.05)$.

Conclusion: Tested antiseptics-disinfectants showed $90 \%$ efficacy to Gram-negative non-fermentative bacteria isolated in the intensive care unit in our hospital. It would be reasonable to perform further efficacy tests for commonly used antiseptics and disinfectants on a regular basis.

Keywords: Acinetobacter baumannii; biofilms; disinfectants; Pseudomonas aeruginosa; resistance.

How to cite: Sebit B, Aksu B, Karahasan Yagcı A. Biofilm production and biocidal efficacy in multidrug-resistant Pseudomonas aeruginosa and Acinetobacter baumannii isolates. Int J Antisep Disinfect Steril 2016;1(1):7-12.

Correspondence: Ayşegül Karahasan Yagci. Marmara Üniversitesi Tip Fakültesi, Mikrobiyoloji ve Klinik Mikrobiyoloji Anabilim Dal, 34640 İstanbul.

Tel: +90532 - 5823582 e-mail: aysegulkarahasan@gmail.com

Submittedः March 30, 2016 Acceptedः April 25, 2016 Available online dateः June 01, 2016 
P seudomonas aeruginosa and Acinetobacter baumannii are common agents responsible for nosocomial infections among other Gram-negative bacteria. A.baumannii ranks the first as the causative agent of nosocomial infections in most centers. ${ }^{[1]}$ This infectious agent is important not only for being the cause of outbreaks associated with a high mortality in the intensive care unit (ICU), but also emergence of multidrug-resistant strains. There has been a significant increase in the prevalence of multidrugresistant strains in recent years. The outbreaks caused by Acinetobacter strains are associated with the ability of bacteria to remain viable for prolonged periods in a dry environment and emergence of antibiotic-resistant infections. ${ }^{[2]}$ P. aeruginosa accounts for 10 to $25 \%$ of all nosocomial infections. ${ }^{[3]}$ This agent, in particular, causes nosocomial infections in patients who receive long-term broad-spectrum antibiotherapy and in those who receive chemotherapy or undergo mechanical ventilation and surgical procedures. ${ }^{[4]}$

It is well-established that bacterial resistance can be acquired not only against antibiotics, but also against disinfectants and antiseptic materials used. Disinfection of the environment and materials with the selection of appropriate disinfectants, and proper use are helpful to prevent the development of many nosocomial infections. ${ }^{[5]}$ In addition, biofilm protects bacteria from phagocytosis and effects of the complement, and this layer forms a physical barrier rendering bacterial resistance to the effects of antibiotics and disinfectant materials. ${ }^{[6]}$

In this study, we aimed to investigate the biofilm production, antimicrobial susceptibility, and biocidal activity of commonly used antiseptics and disinfectants in our hospital setting against $P$. aeruginosa and $A$. baumannii isolates.

\section{Materials and methods}

Between January and December 2014, 164 Pseudomonas spp. and 395 Acinetobacter spp. strains were isolated from patients hospitalized in the intensive care unit at Republic of Turkey MoH, Marmara University, Pendik Training and Research Hospital. Of these isolates, 50 Pseudomonas aeruginosa and 50 Acinetobacter baumannii strains were found to be multidrug-resistant (MDR) strains.

The strains were identified using the mass spectrophotometry (VITEK MS, bioMérieux, France). The antibiotic susceptibility was tested using the disc diffusion test. ${ }^{[7]} P$. aeruginosa strains ${ }^{[8]}$ resistant to all carbapenem, aminoglycoside, and fluoroquinolone groups and A. baumannii strains resistant to all penicillin antibiotics plus at least three of the cephalosporin, quinolone, carbape- nem, and fluoroquinolone groups were considered multidrug-resistant strains. ${ }^{[9]}$ In the study, biofilm forming was tested using A. baumannii ATCC19606 and P. aeruginosa $\mathrm{PAO}-1$ strains positive controls and $P$. aeruginosa PAO-JP3 strain as negative control. ${ }^{[10-12]}$

Clinical strains incubated overnight in the $\mathrm{MacCo}$ nkey agar (BioMerieux, France) and a colony of control strains were inoculated into tubes containing a $5-\mathrm{ml}$ fresh Luria Bertani (LB, Sigma, USA) liquid medium at $37^{\circ} \mathrm{C}$ for 24 hours to calculate the biofilm production. After incubation, $1: 100$ dilution was performed in a fresh LB liquid medium and the dilution was transferred to three wells each containing $100 \mathrm{ml}$ on a sterile, flat-bottomed 96-well polystyrene microplate (Greiner, Germany). The plates were incubated at $37^{\circ} \mathrm{C}$ for 24 hours, and, then the content of the wells was removed and irrigated three times with distilled water. After irrigation, each well was filled with $100 \mu \mathrm{l}$ crystal violet solution $(0.1 \%)$ and the plates remained in room temperature for 10 minutes. The plates were, then, irrigated three times with distilled water to remove excess dye solution and the wells were added $200 \mu \mathrm{l}$ ethanol $95 \%$ to quantify the biofilm layer. Following five minutes of incubation, the absorbance was read in an optic reader (Labsystem Multiskan MS, Thermo Scientific, USA) at $550 \mathrm{~nm}$. The mean absorbance of three wells was recorded for each strain and the experiments were repeated three times. The cut-off value of biofilm production was estimated using the mean absorbance values and standard deviation for non-biofilm forming P. aeruginosa PAO-JP3. A mean + two standard deviations were considered as the cut-off value. ${ }^{[1]}$

Sodium hypochloride (1\%), OPA (Orto-Phthalaldehyde) (0.5\%) (Anios), chlorhexidine (4\%) (Anios), Peracetic acid (2\%) (EcoLab), Peracetic acid + hydrogen peroxide $(0.2 \%+7.5 \%)$ (EcoLab) were used in the disinfectant activity studies. The disinfectant concentrations used in the experiments were as $1 \%, 4 \%, 0.5 \%, 2 \%$, $0.2 \%+7.5 \%$ freshly prepared in sterile distilled water. The suspension test method reported by Michel and Zach was used to evaluate the effects of antiseptic and disinfectants on selected strains. ${ }^{[13,14]}$ This method is a modified version of qualitative and quantitative suspension test recommended by the German Society for Hygiene and Microbiology. A suspension was prepared from Pseudomonas aeruginosa ATCC 15442, Escherichia coli ATCC 10536, Staphylococcus aureus ATCC 6538, clinical A.baumannii $(\mathrm{n}=50)$, and clinical $P$. aeruginosa $(\mathrm{n}=50)$ strains reproduced in the MacConkey agar at $0.5 \mathrm{McF}$ arland standard in a phosphate buffer and the suspension was, then, diluted to 1/100. A $100 \mu$ l of this suspension was transferred into sterile Eppendorf tubes 
containing $100 \mu \mathrm{l}$ disinfectant solution at room temperature $\left(20-25^{\circ} \mathrm{C}\right)$ and serial dilutions were performed after five minutes (eight times). A $10 \mu \mathrm{l}$ of each serial dilution was transferred on tryptic soy agar (TSA) using the drip inoculation method and incubated at $37^{\circ} \mathrm{C}$ for 18 hours. Disinfectant was considered effective in the absence of growth in a specified contact time and concentration; disinfectant solution was considered ineffective, if there was no $99.999 \%$ decline ( $\geq 10$ colony), compared to the positive control. The suspensions of each strain without a disinfectant solution were used as the positive controls.

Statistical analysis was performed using SPSS v15 software (SPSS Inc., Chicago, IL, USA). A p value of $<0.05$ was considered statistically significant.

\section{Results}

The experiments performed on the negative control strain ( $P$. aeruginosa PAO-JP3) showed a cut-off value of 0.169 for the biofilm production. The biofilm production of $P$. aeruginosa and $A$. baumannii was evaluated on the basis of this cut-off value.

Biofilm production was positive in $42.8 \%$ of MDR P. aeruginosa strains and $75.6 \%$ of MDR A. baumannii strains. Biofilm production was also positive in $37.9 \%$ of antibiotic resistant $P$. aeruginosa strains and $71.4 \%$ of
A. baumannii strains (Table 1 ). Biofilm production and disinfectant resistance were significantly higher in the $A$. baumannii group, compared to the $P$. aeruginosa group $(\mathrm{p}<0.05)$.

The rates of efficacy against MDR A. baumannii and $P$ aeruginosa strains $(n=50)$ were found to be $98 \%$ $(n=49 / 50)$ for chlorhexidine, a commonly used hand antiseptic at our hospital, 90\% $(n=45 / 50)$ for sodium hypochlorite, $96 \%(n=48 / 50)$ for OPA, 94\% $(n=47 / 50)$ for $\mathrm{PA}$, and $96 \%$ for peracetic acid/hydrogen peroxide. The rates of efficacy against susceptible $A$. baumannii and $P$. aeruginosa strains (50\%) were $100 \%(n=50 / 50)$ for chlorhexidine, OPA, and PA, 98\% $(n=49 / 50)$ for sodium hypochlorite, and $94 \%(n=47 / 50)$ for peracetic acid/hydrogen peroxide (Table 2).

Three out of 50 P. aeruginosa strains showed resistance against various disinfectants, while only one strain was found to be positive for the biofilm production. The relationship between the biofilm production and disinfectant susceptibility was not significant in $P$. aeruginosa strains. One non-biofilm forming $P$. aeruginosa strain was found to be resistant to both chlorhexidine and peracetic acid/hydrogen peroxide.

A total of 10 strains among A. baumannii isolates were resistant to more than one disinfectant, while only

Table 1. Biofilm production in multidrug-resistant Pseudomonas aeruginosa and Acinetobacter baumannii strains.

\begin{tabular}{|c|c|c|c|c|c|c|c|c|c|c|c|c|}
\hline & \multicolumn{6}{|c|}{ Pseudomonas aeruginosa $(n=50)$} & \multicolumn{6}{|c|}{ Acinetobacter baumannii $(n=50)$} \\
\hline & \multicolumn{2}{|c|}{ MDR } & \multicolumn{2}{|c|}{ Sensitive } & \multicolumn{2}{|c|}{ Total } & \multicolumn{2}{|c|}{ MDR } & \multicolumn{2}{|c|}{ Sensitive } & \multicolumn{2}{|c|}{ Total } \\
\hline & $\mathrm{n}$ & $\%$ & $\mathrm{n}$ & $\%$ & $\mathrm{n}$ & $\%$ & $n$ & $\%$ & $\mathrm{n}$ & $\%$ & $\mathrm{n}$ & $\%$ \\
\hline Biofilm-positive & 9 & 42.8 & 11 & 37.9 & 20 & 40 & 22 & 75.8 & 15 & 71.4 & 37 & 74 \\
\hline Biofilm- negative & 12 & 57.2 & 18 & 62.1 & 30 & 60 & 7 & 24.2 & 6 & 28.6 & 13 & 26 \\
\hline Total & 21 & & 29 & & 50 & & 29 & & 21 & & 50 & \\
\hline
\end{tabular}

MDR: Multidrug-resistant.

Table 2. The efficacy rates of disinfectants against $P$. aeruginosa and $A$. baumannii strains.

\begin{tabular}{|c|c|c|c|c|c|c|c|c|}
\hline & \multicolumn{4}{|c|}{ Pseudomonas aeruginosa } & \multicolumn{4}{|c|}{ Acinetobacter baumannii } \\
\hline & \multicolumn{2}{|c|}{ MDR $(n=21)$} & \multicolumn{2}{|c|}{ Sensitive $(n=29)$} & \multicolumn{2}{|c|}{ MDR $(n=29)$} & \multicolumn{2}{|c|}{ Sensitive $(n=21)$} \\
\hline & $\begin{array}{l}\text { Biofilm- } \\
\text { positive } \\
(n=9)\end{array}$ & $\begin{array}{c}\text { Biofilm- } \\
\text { negative } \\
(n=12)\end{array}$ & $\begin{array}{l}\text { Biofilm- } \\
\text { positive } \\
(n=11)\end{array}$ & $\begin{array}{c}\text { Biofilm- } \\
\text { negative } \\
(n=18)\end{array}$ & $\begin{array}{l}\text { Biofilm- } \\
\text { positive } \\
(n=22)\end{array}$ & $\begin{array}{c}\text { Biofilm- } \\
\text { negative } \\
(n=7)\end{array}$ & $\begin{array}{l}\text { Biofilm- } \\
\text { positive } \\
(n=15)\end{array}$ & $\begin{array}{c}\text { Biofilm- } \\
\text { negative } \\
(n=6)\end{array}$ \\
\hline Sodium hypochlorite & E & 1 & $\mathrm{E}$ & $\mathrm{E}$ & 4 & E & 1 & E \\
\hline OPA & $E$ & E & E & E & 2 & $\mathrm{E}$ & E & E \\
\hline Chlorhexidine & E & 1 & E & $\mathrm{E}$ & $\mathrm{E}$ & $E$ & E & $\mathrm{E}$ \\
\hline Peracetic acid (PA) & E & E & E & $\mathrm{E}$ & 3 & $E$ & E & E \\
\hline $\mathrm{PA}+$ Hydrogen peroxide & E & 1 & 1 & $\mathrm{E}$ & 1 & $E$ & 1 & 1 \\
\hline
\end{tabular}




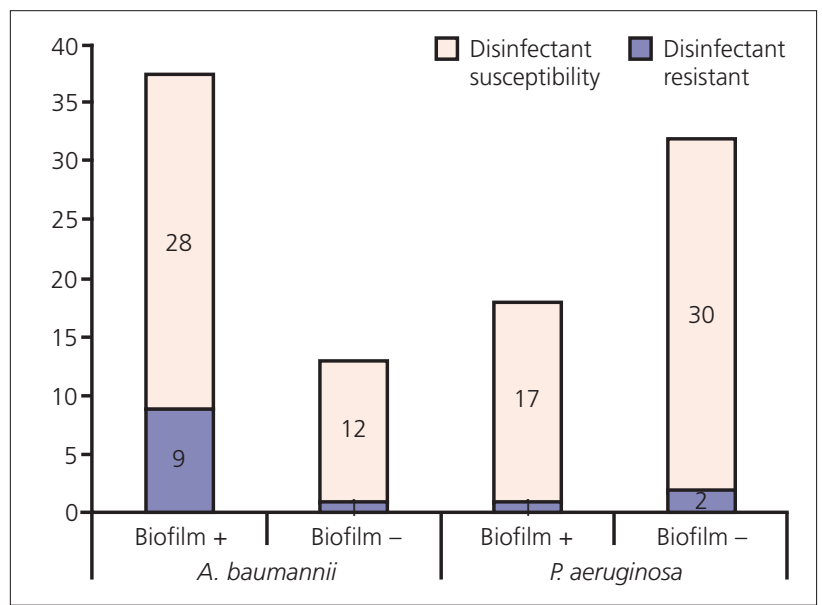

Fig. 1. Disinfectant susceptibility and biofilm production in multidrug-resistant Pseudomonas aeruginosa and Acinetobacter baumannii strains.

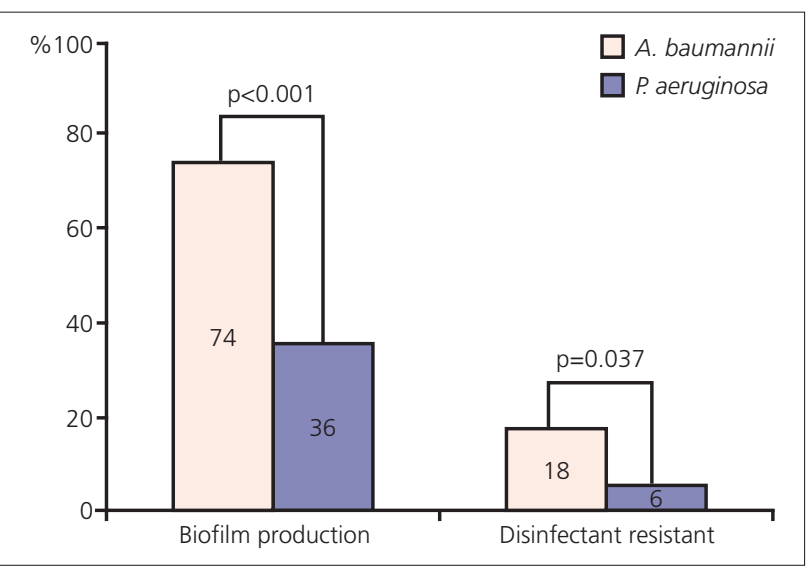

Fig. 2. Disinfectant susceptibility in $P$. aeruginosa and $A$. baumannii strains.

one strain was negative for the biofilm production. Of 10 disinfectant-resistant $A$. baumannii strains, nine were found to be positive for the biofilm production.

In the $A$. baumannii group, three strains were resistant to two disinfectants. Of these strains, two were resistant to sodium hypochlorite and peracetic acid, whereas one strain was resistant to OPA and peracetic acid.

Disinfectant susceptibility and biofilm results are presented in Figure 1.

The rate of disinfectant resistance was significantly higher in A. baumannii strains, compared to P. aeruginosa strains (Figure 2).

\section{Discussion}

The presence of bacteria in the hospital setting leads to continuous contamination of the patients and hospital staff which makes impossible to control hospital infec- tions related to contamination. Thus, disinfection of the environment and hand washing practices are of utmost importance. Pseudomonas aeruginosa and A. baumannii are the most common agents responsible for nosocomial infections among other Gram-negative bacteria. ${ }^{[15]}$ The importance of these agents has been increasing day by day due to their ability to develop antibiotic resistance, which remain viable for prolonged periods on the surfaces and the ability to cause outbreaks. ${ }^{[1]}$

Inappropriate use of antiseptic and disinfectant solutions in terms of contact time with an adequate concentration leads to the selection and emergence of microorganisms resistant to these materials in the hospital setting. In addition, bacteria enclosed with a biofilm layer are more known to be resistant to disinfectant materials, compared to free planktonic form. Several studies have shown that inactivation of microorganisms in the biofilm layer requires the use of up to 1000 -fold higher concentrations. ${ }^{[16,17]}$

When the isolates in the present study were analyzed in terms of biofilm production, $40 \%$ of $P$. aeruginosa strains and $74 \%$ of $A$. baumannii strains produced a biofilm layer. The rate of biofilm production was $75.8 \%$ in multidrug-resistant $A$. baumannii strains and the rate in $P$. aeruginosa strains was $42.8 \%$, showing an inverted trend.

When the relationship between the biofilm production and antiseptic/disinfectant materials used in the study was examined, three out of four resistant strains in the $P$. aeruginosa group were biofilm-negative, while nine out of ten resistant strains in the A. baumannii group were biofilm-positive, as expected (90\%). The efficacy of the disinfectants in the present study was tested on the planktonic form of the bacteria. The study by Spoering and Lewis ${ }^{[18]}$ showed that both planktonic cells and biofilm layer of $P$. aeruginosa exhibited similar resistance to the germicide effects of antibiotics and peracetic acid. The authors emphasized that biocidal efficacy of the bacteria depends on its metabolic activity and bacteria in steady state showed the highest degree of resistance.

Among the materials tested, OPA and peracetic acid showed the highest efficacy against $P$. aeruginosa strains. Using a method similar to that used in the present study, Ekizoglu et al. ${ }^{[19]}$ reported that chlorhexidine $4 \%$ and sodium hypochlorite at a dilution rate of $1: 50(1000 \mathrm{ppm})$ were the most efficient materials against $P$. aeruginosa strains, while sodium hypochlorite at a dilution rate of 1:500 (100 ppm) did not exert efficacy adequately.

Considering $A$. baumannii strains, chlorhexidine $4 \%$ was found to be the most effective disinfectant in 
this group (100\%). Similarly, Ekizoglu et al. ${ }^{[5]}$ found chlorhexidine $4 \%$ to be highly efficient against this agent, while sodium hypochlorite at a dilution rate of 1:50 $(1000 \mathrm{ppm})$ did not show an adequate efficacy. In the present study, sodium hypochlorite showed the lowest efficacy against $A$. baumannii strains with a $90 \%$ success rate. However, sodium hypochlorite $5 \%$ at dilution rates of $1: 10$ and $1: 100$ was found to be among the most efficient disinfectant against clinical $P$. aeruginosa and $A$. baumannii strains in the study by Inan et al. ${ }^{[20]}$

In the present study, five-minute contact time was used in the efficacy tests considering the routine daily practices. Both the rate of the biofilm production and resistance to antiseptic/disinfectant materials were significantly higher in the $A$. baumannii group, compared to the P. aeruginosa group ( $<<0.05$ and $\mathrm{p}<0.001$, respectively). The most efficient disinfectant against all study strains was chlorhexidine (99\%), followed by OPA (98\%) and PA (97\%). Sodium hypochlorite showed the lowest efficacy (94\%) based on the clinical isolates. In another study, Gorgul et al. ${ }^{[21]}$ studied sodium chlorite at a dilution rate of $1: 100$ and reported efficacy against clinical isolates within 15-minute contact time.

In conclusion, antiseptic/disinfectant solutions tested in the present study yielded $90 \%$ and higher efficacy rates, compared to non-fermentative Gram-negative bacteria recovered from the intensive care unit of our hospital. The importance of antisepsis and disinfection must be further emphasized considering patients hospitalized in the intensive care units. Proper application and appropriate concentration are the key drivers for success in disinfection and antisepsis. It would be reasonable for each unit to test the efficacy of antiseptic/disinfectant materials used against the isolated agents on a regular basis.

Conflict of interest $\$$ None declared.

Peer-review: Externally peer-reviewed.

Authorship contributions: Concept - A.K.Y.; Design - A.K.Y.; Supervision - A.K.Y; Resource - A.K.Y.; Materials - B.S.; - Data collection - B.S.; Literature search A.K.Y., B.A.; Writing - A.K.Y., B.A.

\section{References}

1. Fournier PE, Richet H. The epidemiology and control of Acinetobacter baumannii in health care facilities. Clin Infect Dis 2006;42:692-9. Crossref

2. Souli M, Galani I, Giamarellou H. Emergence of extensively drug-resistant and pandrug-resistant Gram-negative bacilli in Europe. Euro Surveill 2008;13(47).
3. Driscoll JA, Brody SL, Kollef MH. The epidemiology, pathogenesis and treatment of Pseudomonas aeruginosa infections. Drugs 2007;67:351-68. Crossref

4. Pier GB, Ramphal R. Pseudomonas aeruginosa. In: Mandell GL, Bennett JE, Dolin R, (eds). Mandell, Douglas and Bennett's Principles and Practice of Infectious Diseases. 7th ed. Philadelphia: Churchill-Livingstone-Elsevier; 2010. p. 2587. Crossref

5. Kuzucu Ç, Baktır E, Uncu H, Acar N, Erdinç Ş. Comparison of the Effectiveness of Antiseptics and Disinfectants against Gram-Negative and Nonfermentative Gram-Negative Bacteria Causing Nosocomial Infections. Turkish J Hosp Infect 2001;5;308-13.

6. Cowen RA. Kelsey-Sykes capacity test: A critical review. Pharm J 1978;220:202-4.

7. Clinical and Laboratory Standards Institute (CLSI): Performance Standards for Antimicrobial Susceptibility testing; Twenty-Fourth Informational Supplement. CLSI document M100-S24, CLSI, Wayne, PA; 2014.

8. Nakamura I, Yamaguchi T, Tsukimori A, Sato A, Fukushima S, Mizuno Y, et al. Effectiveness of antibiotic combination therapy as evaluated by the Break-point Checkerboard Plate method for multidrug-resistant Pseudomonas aeruginosa in clinical use. J Infect Chemother 2014;20:266-9. Crossref

9. Manchanda V, Sanchaita S, Singh N. Multidrug resistant acinetobacter. J Glob Infect Dis 2010;2:291-304. Crossref

10. Holloway BW, Krishnapillai V, Morgan AF. Chromosomal genetics of Pseudomonas. Microbiol Rev 1979;43:73-102.

11. Merritt JH, Kadouri DE, O'Toole GA. Growing and analyzing static biofilms. Curr Protoc Microbiol 2005; Chapter 1:Unit 1B.1. Crossref

12. Pearson JP, Pesci EC, Iglewski BH. Roles of Pseudomonas aeruginosa las and rhl quorum-sensing systems in control of elastase and rhamnolipid biosynthesis genes. J Bacteriol 1997;179:5756-67.

13. Külah C, Doğan B, Gökdal İI,, Yalınay Çırak M, Rota S. The susceptibilities of nonfermentative Gram negative bacteria isolated from intensive care units to various antiseptics and disinfectants. Ankem Derg 2002;16;31-5.

14. Michel D, Zäch GA. Antiseptic efficacy of disinfecting solutions in suspension test in vitro against methicillin-resistant Staphylococcus aureus, Pseudomonas aeruginosa and Escherichia coli in pressure sore wounds after spinal cord injury. Dermatology 1997;195 Suppl 2:36-41. Crossref

15. Chemaly RF, Simmons S, Dale C Jr, Ghantoji SS, Rodriguez $\mathrm{M}$, Gubb J, et al. The role of the healthcare environment in the spread of multidrug-resistant organisms: update on current best practices for containment. Ther Adv Infect Dis 2014;2:79-90. Crossref

16. Mataracı E, Gerçeker A. Evaluation of the Minimum Bactericidal Concentrations of Various Disinfectants against Pseudomonas aeruginosa in Biofilm Cultures. Ankem Derg 2011;25:209-14. Crossref

17. Sultan N. Factors effect activity of disinfectants and tests used 
for disinfectant efficacy. Congress book of 6th National Sterilization and Disinfection, Antalya 2009. p. 121.

18. Spoering AL, Lewis K. Biofilms and planktonic cells of Pseudomonas aeruginosa have similar resistance to killing by antimicrobials. J Bacteriol 2001;183:6746-51. Crossref

19. Ekizoglu MT, Ozalp M, Sultan N, Gür D. An investigation of the bactericidal effect of certain antiseptics and disinfectants on some hospital isolates of gram-negative bacteria. Infect
Control Hosp Epidemiol 2003;24:225-7. Crossref

20. İnan A, Akçay SŞ, Özyürek SÇ, Tekin ST, Erdoğmuş P, Erdem İ, et al. The efficacy of various anticeptics and disinfectants againts some nosocomial pathogens. Türk Mikrobiyol Cem Derg 2009;39:97-102.

21. Görgül G, Başbuğ N, Omürlü $H$. An evaluation of the antibacterial effectiveness of bisdequalinium acetate and sodium hypochlorite. Mikrobiyol Bul 1987;21:289-95.

\section{Çoklu ilaç dirençli Pseudomonas aeruginosa ve Acinetobacter baumannii izolatlarında biyofilm üretimi ve biyosidal etkinlik \\ Burcu SEBIT, Burak AKSU, Ayșegül KARAHASAN YAĞCI}

Amaç: Dirençli Gram-negatif bakterilerin neden olduğu nozokomiyal infeksiyonlar, son yıllarda hastanelerin önemli problemi haline gelmiştir. Antiseptikler ve dezenfektanlar, nozokomiyal infeksiyonlarının önlenmesinde ve infeksiyon kontrol çalışmalarında önemli bir rol almaktadır. Gram-negatif bakterilerin bir kısmı antiseptik ve dezenfektanlara direnç göstermektedir. Bu nedenle, bu dirençli mikroorganizmalar tarafindan oluşturulan nozokomiyal infeksiyonları önlemek için, uygun antiseptik ve dezenfektanların seçimi önemlidir. Bu çalışmada Pseudomonas aeruginosa ve Acinetobacter baumannii izolatlarında antimikrobiyal duyarlılığı ve hastanemizde kullanılan antiseptik ve dezenfektan maddelerin etkinliği ve biyofilm üretiminin dirençle ilişkisi araştırıldı.

Yöntemler: Bu çalışmaya Ocak - Aralık 2014 tarihleri arasında çoklu ilaç dirençli 50 Pseudomonas aeruginosa ve 50 Acinetobacter baumannii suşu alındı. Biyofilm üretimi, mikroplak yöntemi ile spektrofotometrik olarak saptandı. Sodyum hipoklorit, klorhekzidin, orto-fitalaldehit (OPA), perasetik asit (PA) ve perasetik asit/hidrojen peroksit için aktivite süspansiyon yöntemi ile tayin edildi.

Bulgular: Çoklu ilaç dirençli $A$. baumannii ve $P$. aeruginosa suşlarında, hastanemizde sıklıkla kullanılan antiseptik ve dezenfektanlardan klorhekzidin \%98, sodyum hipoklorit \%90, OPA \%96, PA \%94, perasetik asit/hidrojen peroksit $\% 96$ oranında etkili bulundu. Antibiyotik duyarlı A. baumannii ve P. aeruginosa suşlarında ise, klorhekzidin, OPA ve PA $\% 100$, sodyum hipoklorit $\% 98$, perasetik asit/hidrojen peroksit ise $\% 94$ oranında etkin olduğu saptand.. Biyofilm üretimi ile biyosidal direnç ilişkisi incelendiğinde, biyofilm üreten A. baumannii suşlarında herhangi bir dezenfektan-antiseptik direnci \%22 iken, bu oran P. aeruginosa suşlarında \%2'dir. Biyofilm negatif suşlarda dezenfektan-antiseptik direnci A. baumannii için \%2, P. Aeruginosa için ise \%6 idi. Biyofilm üretimi ve dezenfektan direnci, $P$. aeruginosa’ya kiyasla, $A$. baumannii grubunda anlamlı düzeyde yüksek bulundu $(\mathrm{p}<0.05)$.

Sonuç: İncelenen antiseptik/dezenfektanların hastanemiz yoğun bakım ünitesinden izole edilen nonfermentatif Gram-negatif bakterilere karşı \%90 ve üzeri oranda etkin olduğu saptandı. Periyodik aralıklarla, izole edilen patojenler üzerinde kullanılan antiseptik/dezenfektanların etkinliğinin test edilmesi akılcı olacaktır.

Anahtar sözcükler: Acinetobacter baumannii; biyofilm; dezenfektan; direnç; Pseudomonas aeruginosa.

Int J Antisep Disinfect Steril 2016;1(1):7-12 doi: 10.14744/ijads.2016.08208 